\title{
The influence of phytoncides on the immune system of broiler chickens and turkeys
}

\author{
ANDRZEJ KONCICKI, MARCIN ŚMIAŁEK, BARTŁOMIEJ TYKAŁOWSKI, DARIA PESTKA, \\ TOMASZ STENZEL
}

Department of Poultry Diseases, Faculty of Veterinary Medicine, University of Warmia and Mazury

\begin{abstract}
The aim of our study was to investigate the influence of adiSalmo ${ }^{S O L} P F$ dietary supplement, given for 3 days in drinking water, on selected parameters of cell-mediated (Experiment I) and humoral (Experiment II) immunity in chicken and turkey broilers. In Experiment I, birds were randomly divided into two groups of 10 birds each. Group 1 comprised control turkeys or chickens, whereas group 2 birds were administered adiSalmo ${ }^{S O L} P F$. In Experiment II, a total of 69 chickens were divided into three groups (1-3) of 23 birds each. At the age of 25 days, group 1 was given adiSalmo ${ }^{\text {SOL } P F . ~ B i r d s ~ f r o m ~ g r o u p s ~ 1-3 ~}$ were vaccinated at 28 days of age. Group 2 was given adiSalmo ${ }^{S O L} P F$ after vaccination. In Experiment I, a significant increase in percentages of CD4+T lymphocytes in the bursa of Fabricius, cecal tonsils and spleen, CD8+T lymphocytes in the thymus and spleen, CD4+CD8+T lymphocytes in the bursa of Fabricius and ileal mucosa and IgM+B lymphocyte in the ileal mucosa were observed in group 2 chickens. In Experiment I, a significant increase in percentages of CD4+T lymphocytes in the thymus and spleen, $C D 8+T$ lymphocytes in the cecal tonsils and blood, and CD4+CD8+T lymphocytes in the thymus and ileal mucosa was recorded in group 2 turkeys. No differences in percentages of IgM+B lymphocytes were observed between turkey groups. In Experiment II, the highest post-vaccination titers of anti-IB antibodies were observed in group 2, but it was not statistically significant. The results of our study indicate that adiSalmo ${ }^{S O L} P F$ showed immunomodulatory activity in chickens and turkeys.
\end{abstract}

Key words: phytoncides, chickens, turkeys, cell-mediated immunity, humoral immunity.

(Cent Eur J Immunol 2015; 40 (3): 287-291)

\section{Introduction}

In Poland, the use of antibiotic growth stimulators was banned on 1 January 2006 due to increasing levels of microbial resistance to drugs $[1,2]$ and the immunosuppressive activity of selected antibiotics [3]. The above increased the demand for natural alternatives that maximize profitability and efficiency in the poultry industry. One of the most promising alternatives is phytoncides, metabolites of vascular plants characterized by antiprotozoal, antiviral, bactericidal, fungicidal and fungistatic activity [4-10]. Those compounds are commonly used in other poultry supplements on account of their remaining properties, such as immunomodulatory activity. This is an important consideration because the health status of birds and production profitability are largely determined by the immune function which is responsible for vaccine-induced immunity. Effective treatment is always accompanied by the immune system functioning that contributes to the elimination of pathogens and their toxic metabolites, stimulate healing and prevent re-infection. In birds, the immune function can be compromised by infectious [11-13] and non-infectious agents [3, 14-16]. Many pathogens have a predilection for the host's immunocompetent cells and structures, they impair the maturation of lymphocytes, macrophages and granulocytes, the metabolism and function of immunocompetent cells by blocking cytokine receptors, inhibiting interferon production or decreasing the expression of MHC molecules on the surface of infected cells [17-19].

Mucosa-associated lymphoid tissue (MALT) is strongly involved in the immune function in birds. In gastrointestinal mucosa, MALT is represented by the immune structures of the lamina propria and intestinal submucosa that make up gut-associated lymphoid tissue (GALT) [20]. Numerous studies [21-25] have demonstrated that enterocytes in intestinal crypts and villi also play an important role in the immune response of the gastrointestinal tract by cooperating with lymphocytes. The development of those GALT structures can be influenced by the type of feed and feed additives [20]. The complex structure of GALT and its contribution to the immune system of the gastrointestinal tract as well as systemic immunity prompted this study

Correspondence: Andrzej Koncicki, Department of Poultry Diseases, Faculty of Veterinary Medicine, University of Warmia and Mazury, Oczapowskiego 13/14, 10-719 Olsztyn, Poland, e-mail: koncicki@uwm.edu.pl 
into the effects of orally administered phytoncides on the immune function in chickens and turkeys.

The aim of our study was to investigate the influence of the adiSalmo ${ }^{\text {SOLPF }}$ dietary supplement on selected parameters of humoral and cell-mediated immunity in chicken and turkey broilers.

\section{Material and methods}

\section{Dietary supplement}

The adiSalmo ${ }^{\text {SOLPF }}$ (AdiFeed ${ }^{\circledR}$ Sp. z o.o.) dietary supplement for birds contains sensory additives - herbal extracts $(35.55 \%)$, benzoic acid $(0.55 \%)$, anise essential oil $(0.55 \%)$, methyl salicylate $(0.5 \%)$, cinnamon essential oil $(0.3 \%)$, eugenol (isoeugenol) $(0.4 \%)$, thymol $(0.4 \%)$, eucalyptus essential oil (0.3\%), garlic essential oil/garlic oleoresin $(0.3 \%)$, tea tree oil $(0.27 \%)$, mustard essential oil $(0.22 \%)$ and valeric acid $(0.15 \%)$, as well as glycerin and sodium sulfate up to $100 \%$.

\section{Birds, experimental groups and handling procedures}

\section{Experiment I}

Turkeys. The experiment was conducted on twenty 5-week-old Hybrid Converter turkeys which were randomly divided into two groups of 10 birds each. Group 1 was the control, while group 2 birds were administered

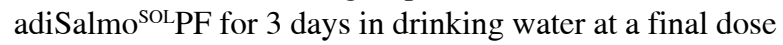
of $1 \mathrm{ml}$ per liter of water.

Chickens. The experiment was conducted on twenty 4-week-old Ross broiler chickens which were randomly divided into two groups of 10 birds each. Group 1 was the control, while group 2 birds were administered adiSalmo-

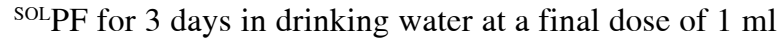
per liter of water.

\section{Experiment II}

Experiment II was conducted on 69 Ross broiler chickens which were randomly divided into three groups (1, 2 and 3 ) of 23 birds each. Beginning at the age of 25 days,

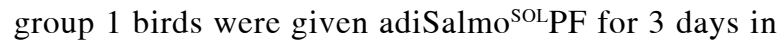
drinking water at a final dose of $1 \mathrm{ml}$ per liter of water. All birds from groups 1, 2 and 3 were vaccinated against infectious bronchitis (IB) at 28 days of age. After vaccination, group 2 birds were administered adiSalmo ${ }^{\text {SOLPF for }}$ 3 days in drinking water at a final dose of $1 \mathrm{ml}$ per liter of water. Group 3 birds did not receive adiSalmo ${ }^{\text {SOLPF }}$ at any time of the experiment.

Both turkeys and chickens were housed in isolated units in a PCL3 biosafety facility. Water and feed were provided ad libitum. The experimental procedures and animal handling procedures were approved by the Local Ethics Committee for Animal Experiments in Olsztyn, Poland.

\section{Vaccine and vaccination}

In experiment II, chickens from groups 1-3 were vaccinated against IBV with Cevac ${ }^{\circledR}$ BRON120L (series 0810A1SKH, expiration date 04/2014) at 28 days of age. The vaccine was administered in drinking water in accordance with the manufacturer's instructions.

\section{Sample collection}

In Experiment I, blood samples were collected from the wing vein of group 1 and 2 chickens and turkeys into sterile tubes containing the EDTA $\mathrm{K}$ anticoagulant for flow cytometry analysis, 10 hours after the administration of

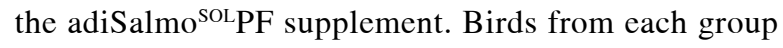
$(n=7)$ were euthanized, and tissue samples were collected from the bursa of Fabricius (BF), thymus, spleen, cecal tonsils (CTs) and $10 \mathrm{~cm}$ of the terminal ileum. The samples were used to isolate mononuclear cells and determine the percentages of $\mathrm{CD}^{+}, \mathrm{CD}^{+}, \mathrm{CD}^{+} / \mathrm{CD}^{+} \mathrm{T}$ cell subpopulations and $\operatorname{IgM}^{+} \mathrm{B}$ cell subpopulation by flow cytometry. In Experiment II, blood samples for serological analyses were collected from 23 birds from groups 1-3 on the day of IB vaccination and two weeks after vaccination.

\section{Serological analysis}

Total serum concentrations of anti-IBV $\operatorname{IgY}(\operatorname{IgG})$ were determined with the use of a commercial immunoenzymatic ELISA kit (IDEXX Laboratories, USA) according to the manufacturer's recommendations. The ELISA assay was performed using the Eppendorf epMotion 5075 LH automated pipetting system, the BioTek ELx405 washer and the BioTek ELx800 absorbance microplate reader.

\section{Isolation of mononuclear cells and flow cytometry}

Peripheral blood mononuclear cells (PBMC) were isolated according to a previously described procedure $[12,23]$. The collected tissue samples were homogenized individually in $1 \mathrm{ml}$ of the RPMI-1640 medium (Sigma-Aldrich, Germany) with 5\% FCS and centrifuged in an automated tissue homogenizer (TissueLyser II, Qiagen, Germany). The homogenates were passed through a sterile $70 \mu \mathrm{m}$ mesh cell strainer (BD Falcon, USA). Tissue residues were discarded, and the isolated cells were washed with the RPMI-1640 medium supplemented with 5\% FCS and centrifuged at $450 \times \mathrm{g}$ for $10 \mathrm{~min}$. Mononuclear cells were isolated by Percoll density gradient centrifugation $\left(900 \times \mathrm{g}, 22^{\circ} \mathrm{C}, 20 \mathrm{~min}\right.$, breaks off). The Percoll medium was prepared by $40 \%$ and $60 \%$ dilution of isotonic Percoll stock solution in Hank's balanced salt solution (Sigma-Aldrich, Germany). After centrifugation, the mononuclear cell layer was carefully transferred to sterile test tubes and washed twice with PBS containing 5\% FCS. Cell pellets were resuspended in $1 \mathrm{ml}$ of PBS. The cells were counted, 
and their viability was evaluated with the Vi-Cell XR Cell Viability Analyzer (Beckman Coulter, USA).

Flow cytometry. $1 \times 10^{6}$ of viable mononuclear cells isolated from peripheral blood and organ tissue samples were transferred to test tubes and stained with FITC-conjugated Mouse Anti-Chicken CD4 (1 : 10, MCA2164F, IgG2b, clone 2-35, Serotec, UK) and PE-conjugated Mouse Anti-Chicken CD8a (1 : 5, MCA2166PE, IgG1, clone 11-39, Serotec, UK) or FITC-conjugated Goat AntiChicken IgM (AAI27F, polyclonal IgG, Serotec, UK). After $30 \mathrm{~min}$ of incubation (on ice and in the dark), the cells were washed twice in $3 \mathrm{ml}$ of PBS and analyzed by flow cytometry in the FACSCanto II cytometer (BD Biosciences, USA). Data were acquired with the use of FACSDiva version 6.1.3 software (BD Biosciences, USA) and analyzed in the FlowJo V10 application (Tree Star Inc., Stanford, CA, USA). The cytometer setup and tracking beads (CST, BD Biosciences, USA) were used to initialize PMT settings. Unstained and single-stained control cells for each fluorochrome were prepared and used for flow cytometry compensation.

\section{Statistical analysis}

The results were processed by the Mann-Whitney $\mathrm{U}$ test for independent samples in Statistica PL V10. Differences were considered statistically significant at $p \leq 0.1$ and highly significant at $p \leq 0.01$.

\section{Results}

The percentages of $\mathrm{CD}^{+}, \mathrm{CD}^{+}$and $\mathrm{CD} 4^{+} \mathrm{CD} 8^{+} \mathrm{T}$ lymphocytes and $\operatorname{IgM}^{+} \mathrm{B}$ lymphocytes in the bursa of $\mathrm{Fa}-$ bricius, thymus, cecal tonsils, ileum, spleen and blood of broiler chickens and turkeys from control groups and ex-

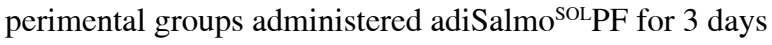
in drinking water at a final dose of $1 \mathrm{ml}$ per liter of water are given in Tables 1 and 2 .

In Experiment I, a significant increase in the percentages of $\mathrm{CD}^{+} \mathrm{T}$ lymphocytes in the bursa of Fabricius, cecal tonsils and the spleen, $\mathrm{CD} 8^{+} \mathrm{T}$ lymphocytes in the thymus and in the spleen, and $\mathrm{CD} 4^{+} \mathrm{CD} 8^{+} \mathrm{T}$ lymphocytes in the bursa of Fabricius and ileal mucosa was observed in group 2 chickens in comparison with control chickens (Table 1). An increase in $\operatorname{IgM}^{+}$B lymphocytes in the ileal mucosa was also noted in group 2 birds (Table 1). In Experiment I, a significant increase in the percentages of $\mathrm{CD} 4^{+} \mathrm{T}$ lymphocytes in the thymus and the spleen, $\mathrm{CD}^{+} \mathrm{T}$ lymphocytes in the cecal tonsils and the blood, and $\mathrm{CD} 4^{+} \mathrm{CD} 8^{+}$ $\mathrm{T}$ lymphocytes in the thymus and ileal mucosa was also recorded in group 2 turkeys (Table 2 ) in comparison with control turkeys. No significant differences in $\mathrm{IgM}^{+} \mathrm{B}$ lymphocyte percentages were observed between turkey groups in Experiment I (Table 2).

The results of a serological analysis investigating the development of humoral immunity in birds vaccinated against IB in Experiment II are presented in Table 3. The highest post-vaccination titers of anti-IB antibodies were observed in group 2 (Table 3 ), but the noted differences were not statistically significant. The lowest vaccine-induced antibody titers were recorded in the group that did

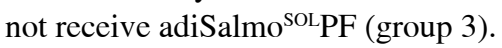

\section{Discussion}

Phytoncide supplements are widely used in poultry production on account of their alleged immunomodulato-

Table 1. Percentages of $T$ and $B$ cells subpopulations in immunological structures of broiler chickens after oral administration of adiSalmoSOLPF $(n=7)$. Results are presented as $\bar{x}, \mathrm{SD}, \mathrm{V} \%$ percentage of investigated immunocompetent cells in each structure of control (group 1) and experimental (group 2) chickens

\begin{tabular}{|c|c|c|c|c|c|c|c|}
\hline Cells & roup & Bursa of Fabricius & Thymus & Cecal tonsils & Ileum & Spleen & Blood \\
\hline & $\begin{array}{l}1 \\
2\end{array}$ & $\begin{array}{ccc}0.92 & 0.17 & 18.89 \\
0.67 & 0.18 & 26.10 \\
U=4.5 ; \boldsymbol{p}=\mathbf{0 . 0 3 7}^{*}\end{array}$ & $\begin{array}{ccc}1.36 & 0.35 & 25.64 \\
1.18 & 0.42 & 35.35 \\
U=12.5 ; p= & 0.423\end{array}$ & $\begin{array}{c}18.203 .3718 .51 \\
23.673 .8216 .14 \\
U=5.0 ; \boldsymbol{p}=\mathbf{0 . 0 4 1}^{*}\end{array}$ & $\begin{array}{l}14.962 .7818 .59 \\
14.412 .7719 .22 \\
U=16 ; p=0.810\end{array}$ & $\begin{array}{ccc}5.50 & 1.49 & 27.02 \\
7.97 & 0.51 & 6.41 \\
U=0.0 ; p= & 0.002^{* *}\end{array}$ & $\begin{array}{rrr}3.94 & 0.72 & 18.30 \\
3.42 & 0.23 & 6.76 \\
U= & 9 ; p=0.174\end{array}$ \\
\hline & $\begin{array}{l}1 \\
2\end{array}$ & $\begin{array}{ccc}3.84 & 1.13 & 29.52 \\
5.12 & 1.91 & 37.41 \\
U=11 ; p= & 0.298\end{array}$ & $\begin{array}{ccc}6.23 & 1.63 & 26.13 \\
8.08 & 0.79 & 9.74 \\
U=6 ; \boldsymbol{p}=\mathbf{0 . 0 6 5}\end{array}$ & $\begin{array}{c}11.701 .99 \quad 17.05 \\
11.791 .6013 .55 \\
U=165 ; p=0.873\end{array}$ & $\begin{array}{c}32.347 .5423 .33 \\
32.974 .4113 .38 \\
U=17.0 ; p=0.936\end{array}$ & $\begin{array}{c}7.932 .7234 .29 \\
13.933 .3424 .01 \\
U=2.0 ; \boldsymbol{p}=\mathbf{0 . 0 0 9}^{* *}\end{array}$ & $\begin{array}{ccc}2.21 & 0.51 & 23.31 \\
1.94 & 0.51 & 26.15 \\
U=13.0 ; p=0.471\end{array}$ \\
\hline $\mathrm{DP} T$ & $\begin{array}{l}1 \\
2\end{array}$ & $\begin{array}{ccc}0.22 & 0.11 & 48.96 \\
0.32 & 0.07 & 20.91 \\
U=7.5 ; \boldsymbol{p}=\mathbf{0 . 0 9 3}^{*}\end{array}$ & $\begin{array}{lll}82.23 & 1.97 & 2.40 \\
80.28 & 1.35 & 1.68 \\
U=8 ; p=0.128\end{array}$ & $\begin{array}{ccc}0.84 & 0.23 & 27.30 \\
1.00 & 0.27 & 27.09 \\
U=15.0 ; p=0.689\end{array}$ & 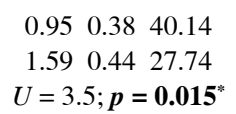 & $\begin{array}{c}0.220 .1358 .59 \\
0.310 .1238 .49 \\
U=11 ; p=0.298\end{array}$ & 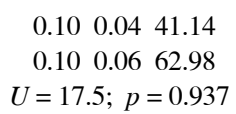 \\
\hline $\mathrm{IgM}^{+} \mathrm{B}$ & $\begin{array}{l}1 \\
2\end{array}$ & 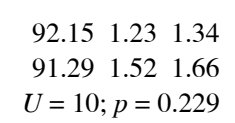 & $\begin{array}{ccc}0.70 & 0.09 & 13.17 \\
0.76 & 0.18 & 23.74 \\
U=16 ; p= & 0.810\end{array}$ & $\begin{array}{ccc}55.35 & 3.73 & 6.74 \\
50.77 & 5.28 & 10.39 \\
U=10.0 ; p= & 0.229\end{array}$ & $\begin{array}{c}11.582 .1918 .87 \\
18.103 .8921 .47 \\
U=1.0 ; \boldsymbol{p}=\mathbf{0 . 0 0 4}\end{array}$ & $\begin{array}{lrr}48.26 & 15.78 & 32.70 \\
49.63 & 6.20 & 12.50 \\
U=14.0 ; p= & 0.575\end{array}$ & $\begin{array}{ccc}6.76 & 0.86 & 12.77 \\
7.19 & 1.62 & 22.47 \\
U=16.0 ; p=0.810\end{array}$ \\
\hline
\end{tabular}

$U$, $p$-result of statistical tests; $D P-$ double positive $C D 4^{+} C D 8^{+} T$ cells

$* p \leq 0.1 ; * * p \leq 0.01$ 
Table 2. Percentages of $\mathrm{T}$ and $\mathrm{B}$ cells subpopulations in immunological structures of turkeys after oral administration of

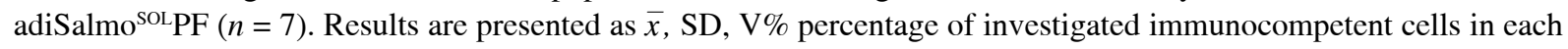
structure of control (group 1) and experimental (group 2) turkeys

\begin{tabular}{|c|c|c|c|c|c|c|c|}
\hline Cells & Group & Bursa of fabricius & Thymus & Cecal tonsils & Ileum & Spleen & Blood \\
\hline $\mathrm{CD}^{+}{ }^{+} \mathrm{T}$ & $\begin{array}{l}1 \\
2\end{array}$ & $\begin{array}{ccc}0.48 & 0.18 & 38.93 \\
0.50 & 0.20 & 40.45 \\
U=17.5 ; p & =0.937\end{array}$ & $\begin{array}{ccc}0.87 & 0.31 & 35.26 \\
0.57 & 0.13 & 22.62 \\
U= & 5.0 ; \boldsymbol{p}=\mathbf{0 . 0 4 1}^{*}\end{array}$ & $\begin{array}{ccc}24.02 & 1.76 & 5.18 \\
33.34 & 5.08 & 15.24 \\
U=16.0 ; p=0.810\end{array}$ & $\begin{array}{c}24.444 .9420 .23 \\
21.154 .3720 .66 \\
U=12.0 ; p=0.379\end{array}$ & $\begin{array}{lrr}24.30 & 3.15 & 12.97 \\
29.16 & 2.63 & 9.02 \\
U=4.0 ; \boldsymbol{p}= & \mathbf{0 . 0 2 6}\end{array}$ & $\begin{array}{rrr}8.91 & 1.71 & 19.18 \\
10.61 & 3.49 & 32.85 \\
U=14.8 ; p & =0.575\end{array}$ \\
\hline $\mathrm{CD}^{+} \mathrm{T}$ & $\begin{array}{l}1 \\
2\end{array}$ & $\begin{array}{ccc}1.38 & 0.19 & 13.76 \\
1.68 & 0.55 & 32.46 \\
U=11 ; p & 0.298\end{array}$ & $\begin{array}{lll}5.86 & 1.63 & 27.28 \\
4.58 & 1.08 & 23.46 \\
U= & 10 ; p= & 0.230\end{array}$ & $\begin{array}{ccc}11.84 & 1.61 & 13.60 \\
18.20 & 2.52 & 13.82 \\
U=0.0 ; \boldsymbol{p}=\mathbf{0 . 0 0 2}^{* * *}\end{array}$ & $\begin{array}{lll}24.40 & 2.67 & 10.92 \\
27.62 & 5.21 & 18.86 \\
U=11 ; p=0.2979\end{array}$ & $\begin{array}{c}38.963 .649 .35 \\
33.875 .4115 .96 \\
U=8 ; p=0.129\end{array}$ & $\begin{array}{c}1.420 .2316 .47 \\
1.990 .6934 .87 \\
U=7 ; \boldsymbol{p}=\mathbf{0 . 0 3 2}^{*}\end{array}$ \\
\hline $\mathrm{DP} \mathrm{T}$ & $\begin{array}{l}1 \\
2\end{array}$ & $\begin{array}{lll}0.52 & 0.25 & 47.68 \\
0.66 & 0.38 & 57.73 \\
U=13 ; p= & 0.471\end{array}$ & $\begin{array}{lll}84.54 & 3.00 & 3.55 \\
88.65 & 1.45 & 1.63 \\
U=4 ; \boldsymbol{p}=\mathbf{0 . 0 3 1}^{*}\end{array}$ & $\begin{array}{lll}5.12 & 1.55 & 30.30 \\
6.18 & 1.03 & 16.75 \\
U=9 ; p= & 0.174\end{array}$ & $\begin{array}{c}22.597 .2432 .03 \\
29.565 .5218 .68 \\
\boldsymbol{U}=\mathbf{5} ; \boldsymbol{p}=\mathbf{0 . 0 4 1}^{*}\end{array}$ & $\begin{array}{lll}3.64 & 0.88 & 24.05 \\
3.25 & 1.13 & 34.92 \\
U=12 ; p & 0.379\end{array}$ & $\begin{array}{lll}0.32 & 0.14 & 42.75 \\
0.46 & 0.19 & 40.65 \\
U=9 ; p=0.174\end{array}$ \\
\hline $\operatorname{IgM}^{+} \mathrm{B}$ & $\begin{array}{l}1 \\
2\end{array}$ & $\begin{array}{ccc}89.34 & 1.99 & 2.23 \\
89.40 & 0.99 & 1.11 \\
U=17 ; p= & 0.936\end{array}$ & $\begin{array}{rrr}0.84 & 0.21 & 25.16 \\
0.89 & 0.17 & 18.96 \\
U= & 13 ; p= & 0.471\end{array}$ & $\begin{array}{ccc}31.95 & 3.18 & 9.94 \\
35.37 & 3.43 & 9.71 \\
U=9.0 ; p & =0.174\end{array}$ & $\begin{array}{ccc}8.45 & 2.96 & 35.03 \\
8.87 & 2.64 & 29.75 \\
U=17 ; p & =0.936\end{array}$ & $\begin{array}{lll}21.80 & 5.42 & 24.85 \\
21.35 & 4.95 & 22.96 \\
U=17 ; p & 0.936\end{array}$ & $\begin{array}{lll}11.31 & 2.89 & 25.38 \\
12.75 & 2.44 & 19.10 \\
U=14 ; p & 0.575\end{array}$ \\
\hline
\end{tabular}

ry effects, but there is a general scarcity of research confirming their immunomodulatory activity. In view of the above, the aim of this study was to investigate the effect of phytoncides contained in the adiSalmo ${ }^{\text {SOL }} \mathrm{PF}$ dietary supplement on selected parameters of cell-mediated immunity in broiler chickens and turkeys and on the development of vaccine-induced humoral immunity in broiler chickens vaccinated against IB.

The analyzed supplement was administered in drinking water, and it could have influenced lymphatic structures in gut-associated lymphoid tissue [20]. GALT consists of lymphoid cells, which are found in the epithelial lining and are distributed in the underlying lamina propria, as well as specialized lymphoid structures such as Meckel's diverticulum, Peyer's patches and cecal tonsils [20]. Those organized lymphoid structures facilitate cooperation between immunocompetent cells and induction of the mucosal immune response. In the intestinal mucosa, the above structures are functionally related to the bone marrow and the spleen $[20,26,27]$, which indicates that the general immune response could be induced locally in GALT. Pre- vious studies [23] have shown that dietary levels of whole grain wheat in feed affect the humoral immune response in turkeys vaccinated against ND and TRT and influence the cell-mediated immune response determined based on the percentages of selected T-cell subpopulations in the blood, ileal mucosa and CTs.

The results of our experiments indicate that phytoncides found in the adiSalmo ${ }^{\mathrm{SOL}} \mathrm{PF}$ supplement, which were administered to birds for 3 days in drinking water at a final dose of $1 \mathrm{ml}$ per liter of water, significantly influenced the counts of $\mathrm{CD}^{+}, \mathrm{CD}^{+}$and $\mathrm{CD} 4^{+} \mathrm{CD} 8^{+} \mathrm{T}$ lymphocytes and $\operatorname{IgM}^{+} \mathrm{B}$ cells in the immune structures of the bursa of Fabricius, thymus, cecal tonsils, ileal mucosa, spleen and blood of broiler chickens and turkeys. A significant increase in $\mathrm{CD}^{+} \mathrm{T}$ cell and $\mathrm{IgM}^{+} \mathrm{B}$ cell counts indicates that adiSalmo ${ }^{\text {SOL }} \mathrm{PF}$ promotes the initiation and regulation of immunological response. The analyzed lymphocytes produce and secrete IL-4, IL-13 and IL-3, which are growth and differentiation promoters for B lymphocytes, thus enhancing humoral immunity during infections with extracellular pathogens $[20,28]$. Despite the absence of

Table 3. Antibody titer against IBV (test ELISA) in blood serum of vaccinated broiler chickens not receiving (group 3) or receiving adiSalmo ${ }^{\text {SOL } P F}$ for three day prior to (group 1) or post IB vaccination (group 2) $(n=23)$

\begin{tabular}{|c|c|c|c|c|}
\hline \multirow[t]{2}{*}{ Group } & \multicolumn{2}{|c|}{ Antibody titer ( $\bar{x}$ SD) } & \multirow[t]{2}{*}{$P$ value } & \multirow[t]{2}{*}{ Statistical difference } \\
\hline & Before vaccination & Post vaccination & & \\
\hline 1 & $77.53 ; 75.73$ & $6389.58 ; 2384.98$ & $<0.0001$ & $* *$ \\
\hline 2 & $77.1 ; 47.89$ & $6944.00 ; 3577.74$ & $<0.0001$ & $* *$ \\
\hline 3 & $64.2 ; 79.74$ & $5776.67 ; 2796.55$ & $<0.0001$ & $* *$ \\
\hline
\end{tabular}


significant differences, similar results were noted in our studies investigating the levels of vaccine-induced anti-IB antibodies which were higher in chickens given adiSalmoSOLPF (before or after vaccination) than in birds that did not receive the supplement at any time of the experiment.

$\mathrm{CD}^{+}$and $\mathrm{CD}^{+}{ }^{+} \mathrm{CD} 8^{+} \mathrm{T}$ cell subpopulations are responsible for numerous immune functions, inter alia they are known to eliminate cancer cells and cells infected with viruses and other microorganisms, and inhibit the replication of viruses by producing and secreting various cytokines, including IFN- $\gamma[20,28]$. In our study, percentages of those cells increased in the immunological structures and blood of chickens and turkeys receiving the adiSalmo ${ }^{\text {SOL }} \mathrm{PF}$ supplement thus indicating that the analyzed supplement stimulates the immune system to perform its physiological functions. Additionally, Martinez et al. [7] demonstrated that essential oils, in particular oregano, cinnamon, melaleuca, clove, rosemary and eucalyptus essential oils, inhibit the proliferation of E. coli, Salmonella spp. and Staphylococcus aureus in culture media.

The results of our study indicate that adiSalmo ${ }^{\text {SOLPF, }}$ administered to birds for 3 days in drinking water at a final dose of $1 \mathrm{ml}$ per liter of drinking water, shows immunomodulatory activity in both chickens and turkeys.

\section{The authors declare no conflict of interest.}

\section{References}

1. Truszczyński M, Pejsak Z (2011): Causes of the particularly rapid rise of antibiotic resistance of bacteria and action against the risk for human health originating from zoonotic bacteria. Med Weter 67: 75-78.

2. Truszczyński M, Pejsak Z (2013): Sources and routes of spread of antibiotic resistance of bacteria. Med Weter. 69: 203-207.

3. Tykałowski B, Stenzel T, Śmiałek M, et al (2013): Influence of the oral administration of oxytetracycline on selected parameters of cellular immunity in turkeys. Med Weter 69 432435.

4. Barbosa L, Rall V, Fernandez A, et al. (2009): Essential oils against food borne pathogens and spoilage bacteria in minced meat. Foodborne Pathog Dis 6: 725-728.

5. Bassole IHN, Juliani HR (2012): Essential oils in combination and their antimicrobial properties. Molecules 17: 3989-4006.

6. Ingham JL (1973): Disease resistance in higher plants. The concept of pre-infectional and post inflectional resistance. Phytopathol 78: 314-335.

7. Martinez K, De Santiago L, Care S, et al. (2012): Antibacterial effects of commercial essential oils on bacteria. J Nat Sci 1: 1-3.

8. Roeske W (1955): Zarys fitoterapii: farmakologia i receptura ziół leczniczych. Państwowy Zakład Wydawnictw Lekarskich, Warszawa.

9. Tokin B (1953): Fitoncydy. Państwowe Wydawnictwo Rolnicze i Leśne, Warszawa.
10. Williams CA, Harborne JB, Newman M, et al. (1997): Chrysin and other leaf exudate flavonoids in the genus Pelargonium. Phytochemistry 46: 1349-1353.

11. Guiro S, Koncicki A (2004): Vaccination against NDV in turkeys infected by haemorrhagic enteritis virus. Med Weter 60: 871-873.

12.Koncicki A, Tykałowski B, Stenzel T, et al. (2012): Effect of infection of turkeys with haemorrhagic enteritis adenovirus isolate on the selected parameters of cellular immunity and the course of colibacillosis. Pol J Vet Sci 15: 215-220.

13. Sharma JM, Karaca K, Pertile T (1994): Virus-induced immunosuppression in chickens. PoultSci 73: 1082-1086.

14.Dietert RR, Golemboski KA, Austic RE (1994): Environment-immune interactions. PoultSci 73: 1062-1076.

15. Jankowski J, Zduńczyk Z, Sartowska K, et al. (2011): Metabolic and immune responses of young turkeys originating from parent flocks fed diets with inorganic or organic selenium. Polish J Vet Sci 14: 353-358.

16. Tykałowski B, Stenzel T, Mikulski D, et al. (2011): The level of electrolytes and percentage of T-lymphocyte subpopulations in blood of broiler chickens fed mixtures with different contents of sodium chloride. Bull Vet Inst Pulawy 55: 333337.

17. Nagaraja KV, Patel BL, Emery DA, et al. (1982): In vitro depression of the mitogenic response of lymphocytes from turkeys infected with hemorrhagic enteritis virus. Am J Vet Res 43: 134-136.

18. Nagaraja KV, Emery DA, Patel BL, et al. (1982): In vitro evaluation of B-lymphocyte function in turkeys infected with hemorrhagic enteritis virus. Am J Vet Res 43: 502-504.

19. Suresh M, Sharma JM (1995): Hemorrhagic enteritis virus induced changes in the lymphocyte subpopulations in turkeys and the effect of experimental immunodeficiency on viral pathogenesis. Vet Immunol Immunopathol 45: 139-150.

20. Smith AL, Beal R (2008): The avian enteric immune system in health and disease. In: Davison F, Kaspers B, Schat KA (eds.). Avian Immunology. Elsevier Ltd; 243-271.

21.Hermiston ML, Gordon JI (1995): Organization of the crypt-villus axis and evolution of its stem cell hierarchy during intestinal development. Am J Physiol 268: 813-822.

22. Smith MW, Peacock MA (1989): Comparative aspects of microvillus development in avian and mammalian enterocytes. Comp Biochem Physiol A93: 617-622.

23. Tykałowski B, Śmiałek M, Pestka D, et al. (2014): The effect of whole wheat feeding on selected immune parameters in growing male turkeys. Pol J Vet Sci 17: 255-262.

24.Uni Z, Noy Y, Sklan D (1995): Post hatch changes in morphology and function of the small intestines in heavy- and light-strains chicks. Poult Sci 74: 1622-1629.

25. Uni Z, Geyra A, Ben-Hur H, Sklan D (2000): Small intestinal development in the young chick: crypt formation and enterocyte proliferation and migration. Br Poult Sci 41: 544-551.

26. Bar-Shira E, Sklan D, Friedman A (2003): Establishment of immune competence in the avian GALT during the immediate post-hatch period. Dev Comp Immunol 27: 147-157.

27.Jeurissen SHM, Vervelde L, Janse M (1994): Structure and function of lymphoid tissue in the chicken. Poult Sci Rev 5: 183-207.

28. Lasek W (2002): The mucosal immune system. In: Immunology. Gołąb J, Jakóbisiak M, Lasek W (eds.). PWN, Warszawa; 288-299. 